\title{
Single-dose Azithromycin for Childhood Cholera
}

\author{
WASIF Ali Khan \\ Scientist, Clinical Sciences Division, ICDDR B, 68 Shaheed Tajuddin Ahmed Sharani, Mohakhali, Dhaka-1212, Bangladesh. \\ wakhan@icddrb.org
}

I $\mathrm{n}$ this issue, Kaushik, et al.(1), reconfirmed the statement made in an earlier study "singledose azithromycin has been established as an effective drug for the treatment of cholera caused by susceptible strains of $V$ cholera in both adults and children" the same regimens were compared in adults with severe cholera(2).

Though the study design was almost consistently followed with the recent publication in Lancet and NEJM but the authors used different outcome variable ( $72 \mathrm{~h}$ instead of $48 \mathrm{~h}$ ), that made it difficult to compare it with earlier studies(2-5). Although, in the discussion, authors did state the discrepancies in using different criteria for the clinical and bacteriological success rates, among the references quoted, the success rate was based on $48 \mathrm{~h}$ definition in 4 out of 5 relevant trial articles. Therefore, for a better comparison, I reexamined the dataset of our study of azithromycin in childhood cholera(4) and noted the rate of clinical and bacteriological success as $81 \%$ and $84 \%$, respectively at $72 \mathrm{~h}$. Thus, it is important that an investigator conducting same type of clinical trial in different population should try to use similar outcome variables as in earlier published work.

The objective of evaluating single dose treatment in addition to fluid replacement for children with cholera is to manage such patients in resource limited set-ups like during epidemic situation or man-made disasters, such as observed in Goma in 1994 and Zimbabwe in 2008-9(6,7). Since one of the manifestation of cholera patients is vomiting, it is important to know how many patients vomited within first 10 minutes who were re-administered

second dose, and the use of unscheduled intravenous fluids between the groups. These are the points to be considered in planning a policy on the strategy for a single-dose therapy. Unfortunately we have no clue on these issues from this study.

It is not clear how often the intake and output were measured. The other major concern is with the definition of clinical relapse. The earliest point when the patients can be discharged is if watery stool resolves at $72 \mathrm{~h}$ ( 3 day) and we know the mean duration of diarrhea among the azithromycin treated group was $54 \mathrm{~h}$ ( $>2$ days), whereas it is stated for defining clinical relapse there has to be a minimum of $24 \mathrm{~h}$ without watery stool. I doubt if the patients were kept that long in the hospital (24h without diarrhea), thus resulting in no clinical relapse in either treatment group. Ideally, if all patients were kept in the hospital for 5 days, they could have defined the clinical and bacteriologic relapse more confidently as observed in earlier studies.

In the discussion section, the authors have argued that by conducting their study at a tertiary care hospital they provided a more realistic picture of diarrheal disease burden compared to trial at diarrheal disease hospital. This argument is surprising since disease burden study in a tertiary care hospital does not reflect the general population and moreover this was not the objective of the study. Conducting the study at a diarrheal disease facility, on the other hand, has the advantage that the trial can be completed faster producing equally valid results.

The major strength of the study was the gender balance although I wonder how they could ensure 
that urine and stool were not misinterpreted especially when the subjects were only 2-12 years; no information was available on this.

Finally, as a reviewer, it is good to see the efficacy of azithromycin as a single dose but this also has a negative implication in developing countries like India and Bangladesh, where drugs can be purchased over the counter. When the lay people/ pharmacists know that single dose azithromycin works against cholera it is likely that the use of this agent will increase exponentially, a market that pharma-ceuticals will always like to see. Thus it is important for the policy makers, regulatory bodies and drug control agencies to keep a vigil on the use of antimicrobial agents. We have to realize that options diminishing are against multiple drug resistance (MDR) V. cholerae.

Funding: None.

Competing interests: None stated.

\section{REFERENCES}

1. Kaushik JS, Gupta P, Faridi MMA, Das S. Singledose azithromycin versus ciprofloxacin for cholera in children: a randomized controlled trial. Indian Pediatr 2010; 47: 309-315.

2. Saha D, Karim MM, Khan WA, Ahmed S, Salam
MA, Bennish ML. Single-dose azithromycin for the treatment of cholera in adults. N Engl J Med 2006; 354: 2452-2462.

3. Khan WA, Bennish ML, Seas C, Khan EH, Ronan A, Dhar U, et al. Randomized controlled comparison of single-dose ciprofloxacin and doxycycline for cholera by Vibrio cholerae $\mathrm{O} 1$ or O139. Lancet 1996; 348: 296-300.

4. Khan WA, Saha D, Rahman A, Salam MA, Bogaerts J, Bennish ML. Comparison of singledose azithromycin and 12 dose, 3-day erythromycin for childhood cholera: a randomized, double-blind trial. Lancet 2002; 360: 1722-1727.

5. Saha D, Khan WA, Karim MM, Chowdhury HR, Salam MA, Bennish ML. Single-dose ciprofloxacin versus 12-dose erythromycin for childhood cholera: a randomised controlled trial. Lancet 2005; 366: 1085-1093.

6. Siddique A, Salam A, Islam M, Akram K, Majumdar R, Zaman K. Why treatment centres failed to prevent cholera deaths among Rwandan refugees in Goma, Zaire. Lancet 1995; 345: 359361.

7. World Health Organization, Cholera in Zimbabwe: Epidemiological Bulletin Number 24 Week 21 (17 - 23 May 2009). Available at http://www.who.int/ hac/crises/zwe/en/index.html. Accessed 20 June, 2009. 